\title{
A Study on Universal Design Critical Factors of the Urban Railway Station
}

\author{
도시철도 역사의 유니버설 디자인 기준요소에 관한 연구 \\ Kang, Byoung-Keun* 강병근 | Lee, Joo-hyung** 이주형 | Kim, Sang-Woon*** 김상운 | \\ Kang, Tae-Sung**** 강태성 | Byun, Seong-Heon ${ }^{\star \star \star \star ~}$ 변성헌
}

\begin{abstract}
Purpose: The number of the transportation poor has been steadily increased, and also the social perspective toward the disabled has been changed. Thus, Universal Design has been needed. In particular, the unknown majority of the transportation poor have frequently used the urban railway facilities which should reflect the ideals and principles of Universal Design. However, previous research has not focused on the study on critical factors of Universal Design. Based on this observation, the present study aims to find out Universal Design critical factors of urban railway station. Methods: This study explores the criteria of planning Universal Design in the urban railway station by analyzing and comparing the similar criteria used in both domestic areas and foreign countries. Result: Findings from this study are as follows. First, we found out the critical factors of Universal Design in the urban railway station by comparing and analyzing the similar criteria previously used. Second, this study also suggests the better directions toward the domestic criteria relating to the urban railway system. Third, we found the need of the universal standard as well as individually corresponding strategy. Moreover, we found the need of preparing the critical factors for the physical environments as well as the human service. Implications: The further research on findings of the planning criteria will have been continued on the basis of findings of the present study.
\end{abstract}

Keywords Urban Railway Station, Universal Design, the Transportation Poor

주 제 어 도시철도역사, 유니버설디자인, 교통약자

\section{Introduction}

\subsection{Background and Purpose}

2012년 말 현재 우리나라의 교통약자1)는 전체인구 대비 $24.63 \%$ 에 해당하는 약 1,254만 명으로 분류할 수 있으며, 2023년 전체 인구대비 약 $30.56 \%$ 인 1,582만 명까지 증가할 것으로 예상하고 있다2). 교통약자의 증가와 더불어 장애를 바

* Member, Professor, Dr.-ing, College of Architecture, Konkuk University(Primary author: prof-k@hanmail.net)

** Member, Researcher, Candidate for Ph.D., Architectural Barrier-free Institute of Konkuk University(Corresponding author: alchmate@naver.com)

*** Member, Research Professor, Ph.D., Architectural Barrier-free Institute of Konkuk University

**** Member, Researcher, Candidate for Ph.D., Architectural Barrier-free Institute of Konkuk University
라보는 사회적 관점도 변화하고 있다. 현재 대부분의 연구자 들이 동의하는 장애란 정신적, 육체적 건강상태가 주변의 사 회적, 물리적 환경과 작용하면서 나오는 결과물이란 것이 다.(WHO, 2001)3) 이러한 장애에 대한 새로운 혹은 장애를 바 라보는 새로운 관점은 2006년 UN의 장애인 인권회의에서 채

1) 교통약자는 영어의 "the Transportation vulnerable"에 해당하는 용어로 이해할 수 있으며, 자동차에 비해 약자라고 할 수 있는 보행자 및 자전거 이용자, 젊고 건강한 사람에 비해 약자인 고령 자, 장애인, 임산부, 어린이, 짐을 든 사람 및 환자와 같은 일시적 장애인 등이 이에 속한다. 이러한 교통약자의 개념은 광의의 개 념인 "transportation poor"와 협의의 개념인 "the mobility handicapped"로 구분할 수 있다.

2) 2012년 보건복지부 장애인등록현황, 통계청 고령자통계 및 출생 통계, 안전행정부 주민등록 인구통계를 참조

3) World Health Organization., 2001, International classification of functioning, disability and health, WHO, Geneva 
택되기도 하였다.4) 장애에 대한 이러한 새로운 패러다임변화 는 다양한 사용계층의 요구를 충족시킬 수 있는 디자인 철학 의 변화를 이끌어왔다. '모두를 위한 디자인(Design for All)', '유니버설 디자인(Universal Design)' 등 다양한 용어로 등장 한 이러한 디자인 철학은 기존의 장애인만을 위한 특별한 디 자인에서 노인, 어린이, 임산부, 무거운 짐을 든 사람, 부상 등 에 의한 일시적 장애를 겪게 되는 모든 사람을 배려하는 것으 로 변화되고 있다.

유니버설 디자인은 단순히 장애인이나 고령자 등을 배려한 특별한 디자인이 아니라 모두에게 유용한, 사회적 통합을 위 한 개념이라 할 수 있다. 이러한 유니버설 디자인은 변화하는 사회적 환경, 제도적 변화, 복지정책의 확대 흐름 등에 따른 사회적 관심이 높아지면서, 지자체별로 디자인 기준이나 조례 제정 등의 움직임들에 반영되고 있다. 이러한 상황에서 사회 적약자, 교통약자의 수송 분담율이 높은 도시철도에도 사회통 합적인 유니버설 디자인 환경 조성이 필요하며, 이를 완성하 기 위한 계획기준 수립이 필요하다. 그러나 현행 관련 기준은 교통여객시설이라는 큰 범주로만 규제하고 있어 각 교통유형 시설별 특성을 반영하지 못하고 있는 실정이다.

이에 본 연구는 국내외 유니버설 디자인 계획기준 비교를 통해 도시철도 역사의 유니버설 디자인 계획기준 개발을 위 한 기준요소를 도출하고자 한다.

\subsection{Methods of Research}

연구의 방법으로는 도시철도와 유니버설 디자인에 대한 이 론적 고찰과 교통약자의 도시철도 역사 이용특성 및 배려공 간을 분석한다. 또한, 각 배려 항목 및 공간별 국내외 기준을 비교분석함으로써, 유니버설 디자인 계획기준 항목과 적용요 소를 도출하도록 한다. 본연구의 진행을 도식화하면 아래의 [Figure 1]과 같다.

\begin{tabular}{|c|c|c|}
\hline $\begin{array}{l}\text { Background } \\
\text { /Purpose }\end{array}$ & \multicolumn{2}{|c|}{$\begin{array}{l}\text { Demand of Universal Designed Society and environment } \\
\text { /Elicitation of UD element for Urban Railway Station }\end{array}$} \\
\hline $\begin{array}{l}\text { Theoretical } \\
\text { Study }\end{array}$ & \multicolumn{2}{|c|}{$\begin{array}{c}\text { Transportation poor, Urban Railway Station } \\
\text { and Idea of Universal Design }\end{array}$} \\
\hline & Korea & Japan, EU, United Kingdom \\
\hline $\begin{array}{l}\text { Survey } \\
\text { /Compare }\end{array}$ & $\begin{array}{l}\text { Acts and regulations } \\
\text { concerning with UD and } \\
\text { transport station }\end{array}$ & $\begin{array}{l}\text { Acts and regulations } \\
\text { concerning with UD and } \\
\text { transport station }\end{array}$ \\
\hline Conclusion & \multicolumn{2}{|c|}{ Findings of UD Critical Factors for Urban Railway Station } \\
\hline
\end{tabular}

[Figure 21] Study Flowchart

\subsection{Previous Studies Review}

현재까지 국내에서 이루어진 철도관련 시설을 유니버설 디 자인적 측면에서 연구한 논문들을 살펴보자면 우선 김영수, 강병근(2002:35-45)5)은 서울시 지하철 1호선에서 8호선까지

4) United Nations, 2006, Convention on the Rights of Persons with Disabilities, G.A. Res. 61/106, NY

5) Kim, Young-Soo, Kang, Byoung-Keun, 2002, Study about
모든 역사를 대상으로 하여 장애인 편의시설의 충족여부를 분석하였고 1 4호선의 역사가 그 이후에 지어진 역사에 비해 서 장애인 편의시설(엘리베이터, 에스컬레이터, 휠체어리프트 등)이 부족함을 지적하였다. 황원경, 신경주(2002:130-134)6) 는 국내교통시설에 많은 장애물이 산재해 있음을 지적하였으 며, 국내의 지하철시설을 대상으로 하여 유니버설디자인의 측 면에서 평가가 가능한 체크리스트의 개발을 시도하였다. 조영 행(2007:115-125)7)은 부산시 지하철 역사를 대상으로 장애인 편의시설의 실태를 파악하였는데 이동시설, 내부시설, 위생시 설, 안내 및 기타 시설로 항목을 나누어 분석하였다. 그 결과 예전에 지어진 역사가 최근에 지어진 역사보다 장애인편의시 설이 부족함을 지적하였다. 또한 장애인용 승강기의 설치, 계 단 손잡이의 위치, 크기 등이 취약함을 지적하였다. 문서현, 신경주(2010:357-368)8)은 한국과 일본에서의 철도시설 관 련 기준을 바탕으로 체크리스트의 작성한 이후 이를 통해 인천공항철도의 이용자 시설을 평가를 하였다. 그 결과 주출 입구, 자판기, 매표소, 장애인 화장실의 시설 개선이 시급하 다고 지적하였다. 노지혜, 강병근, 성기창, 박광재, 김상운 (2011:43-51)9)은 국내 법규를 토대로 작성한 실태조사표를 기준으로 철도시설의 장애요소 및 문제점을 도출하였다. 그 결과 각 항목별 세부기준 및 교통약자 유형별 상세 대응기준 수립의 필요성과 주차장 시설의 개선이 필요하다고 언급하였 다. 김선태, 변혜령, 최령(2013:69-80)10)은 수원역과 병점역을 대상으로 유니버설디자인의 관점에서 평가하고 개선안을 제 안했는데 평가결과 주출입구의 개폐형식, 승강기의 위치, 장 애인화장실의 위치, 개찰구의 작동방식, 점자블록의 그릇된 설치 등의 개선이 필요하다고 지적하였다. 전용석 (2013:

present facilities for the handicapped and the direction of improvement. 대한건축학회논문집 계획계 제 18 권 제4호, 대한 건축학회, Seoul

6) Hwang, won-kyong, shin, kyung-joo, 2002, A Study on Environmental Assessment and Countermeasures for Subway Stations. 한국실내디자인학회 학술발표대회논문집 제4권 제4 호, 한국실내디자인학회, Seoul

7) Cho, Young-Hang, 2007, The Analysis of the Facilities for the Disabled Person in the Busan Subway. 대한건축학회논문집 계획계 제23권 제8호, 대한건축학회, Seoul

8) Moon, Suh-Hyun. Shin Kyung-Joo, 2010, A Study on the Evaluation of Airport Railroad User Facilities through Checklist. 대한건축학회논문집 계획계 제 26 권 제 1 호, 대한건축 학회, Seoul

9) Noh, Ji-hye, Kang, Byoung-keun, Seong, Ki-chang, Park, Kwang-jae, Kim, Sang-woon, 2011, A Study on the Analysis and Investigation about Barrier-Free in Railroad Facilities, 한 국의료복지시설학회논문집 제 17 권 3 호, 한국의료복지시설학 회, Seoul

10) Kim, Sun-Tae, Byun, Hea-Ryung, Choi, Ryung, 2013, Evaluation and Analysis on the Characteristics of User-friendly Rail Passenger Facilities according to Universal Design. 대한건축학회논문집 계획계 제29권 제1호, 대한건축학 회, Seoul 
75-84)11)은 「장애인·노약자.임산부등의편의보장에관한법률」 과 「교통약자의 이동편의 증진법 $\lrcorner$ 을 바탕으로 광역시에 위치 한 역사들의 편의시설을 평가하였다. 그 결과 시각장애인을 위한 편의시설이 상대적으로 미비하며, 부분적으로 한 층 전 체가 장애인용 화장실, 점자표지판 등의 장애인편의시설이 생략되어있음을 지적과 함께「교통약자의 이동편의 증진법」 의 세부기준에 대해 재정비의 필요성을 언급했다.

위와 같은 선행연구를 고찰한 결과 철도관련 시설과 관련 된 다양한 연구들이 진행되었으나 이전의 연구들은 실태조사 위주의 연구로 인해 철도시설과 관련하여 시설적 개선방향을 지적하는 경우가 많았으며, 철도역사의 UD계획 기준 및 요소 에 관해서는 연구가 미비함을 알 수 있었다.

\section{Theoretical Study}

\subsection{The Idea of Universal Design}

1950년대 미국에서 장애가 있는 군인 등의 요구에 의해 생 겨난 무장애디자인(Barrier-Free Design) 이후로 장애인을 배 려한 다양한 디자인 용어 및 철학이 다양하게 나타났다. 무장 애디자인, 접근 가능한 디자인(Accessible Design)이라는 용어 가 보편적으로 사용되어 왔고, 이러한 디자인은 특별한 사람 (장애인 등)을 위해 특별한 시설(편의시설)을 제공 하는 것을 의미했다. 이는 디자이너에게 장애인과 비장애인을 분리하여 생각하게 만들었고, 장애인 등이 시설 및 도시공간을 이용하 고 접근할 수는 있지만, 그 안에는 보이지 않는 차별이 존재하 고 있었다.

이러한 내재적 문제로 인해 나타난 유니버설 디자인은 장 애 유무를 떠나, 모든 사람의 신체적, 정신적 능력의 다양성을 인정하고 도시공간을 이용함에 있어 차별 없는 사회를 조성 하고자 한다. 로널드 메이스에 의해 정의된 유니버설 디자인 (Universal Design, 이하 UD)의 의미는 '모든 공산품, 건물, 외 부공간을 모든 사람이 이용 가능하도록 디자인 하는 것'(Mace et al, 1991)으로, 다양한 범위의 인간 능력을 고려 하여 최대한 사용가능하도록 제품과 환경(시설물, 주거, 도시 공간 등)을 디자인 하는 것을 의미한다. 즉, '인간의 다양성을 존중하고, 모든 사람을 수용하여 일상생활 안에서의 통합을 증진하는 디자인 철학'(Story et al, 1998)을 의미한다.

미국의 경우 1961년 미국표준협회(후에 ANSI로 변경)에서 무장애빌딩을 위한 국가 표준을 수립하였고, 앞서 언급한 디 자인 철학의 변화에 따라 1973년 재활법에 내재적으로 UD의 원칙을 포함하였고, 이후 교육과 시설물과 관련된 법규 및 기 준에 확대 적용하고 있다. 유럽의 경우도 EIDD-Design for All

11) John, Yong-Seok, 2013, A Study Evaluation on the Accommodations of Railroad station Facilities in relation to Universal Design, 대한건축학회논문집 계획계 제29권 제11호, 대한건축학회, Seoul
Europe을 중심으로 회원국별 UD의 원칙과 철학을 적용하여 관련 법규와 기준에 확대 적용하고 있다.

한국의 경우 1981년 심신장애자복지법이 시행된 이후 시 설물 관련 법규와 기준이 지속적으로 개정 및 제정되어 왔으 며, 디자인 철학에 있어서도 점차 모두를 배려하는 방향으로 변화하고 있다. 우리나라의 유니버설 디자인 관련 법규 및 제 도의 변화를 살펴보면 다음 [Table 1]과 같다.

[Table 1] Concerning of Universal Design Acts and Regulations in Korea

\begin{tabular}{|c|c|c|}
\hline Years & Acts & Contents or Significance \\
\hline '81 & \begin{tabular}{|l|} 
심신장애자복 \\
지법
\end{tabular} & $\begin{array}{l}\text { Factors relevant to housing for the disabled } \\
\text { was separately considered. } \\
\text { Focused on the disable's accessibility to the } \\
\text { public facilities such as roads, parks, public } \\
\text { building, and transportation facilities. }\end{array}$ \\
\hline 85 & 건축법 & $\begin{array}{l}\text { Established the act related to the physically } \\
\text { handicapped's accessibility to the facilities in } \\
1985 \text {. } \\
\text { Added the act relating to elevators as well as } \\
\text { toilets for them in } 1986 . \\
\text { Proposed the detailed rules related the } \\
\text { disabled facilities in } 1988\end{array}$ \\
\hline 89 & 장애인복지법 & $\begin{array}{l}\text { the Mentally and Physically Handicapped } \\
\text { Persons Welfare Act. was changed in to the } \\
\text { Disabled Welfare Act. } \\
\text { In 1990, the building rule for the disabled } \\
\text { facilities was emphasized. } \\
\text { This rule did not actually reflect the } \\
\text { improvement of the disabled facilities. }\end{array}$ \\
\hline ‘97 & $\begin{array}{l}\text { 장애인·노인. } \\
\text { 임산부등의편 } \\
\text { 의증진보장에 } \\
\text { 관한법률 }\end{array}$ & $\begin{array}{l}\text { Universal Design, needed for the disable, was } \\
\text { considered in revising the rules. } \\
\text { Guaranteed the disable' accessibility, involving } \\
\text { the old, the pregnant, and the weak, to } \\
\text { information related to facilities for themselves } \\
\text { so that they can safely use facilities by } \\
\text { themselves. }\end{array}$ \\
\hline 06 & $\begin{array}{l}\text { 교 통 약 자 의 } \\
\text { 이동편의 } \\
\text { 증진법 }\end{array}$ & $\begin{array}{l}\text { Separately dealt with the details related to } \\
\text { transportation such as road, transportation } \\
\text { system, and passengers' convenience facilities. }\end{array}$ \\
\hline 08 & $\begin{array}{l}\text { 장애인차별금 } \\
\text { 지 및 권리구 } \\
\text { 제 등에 관한 } \\
\text { 법률 }\end{array}$ & $\begin{array}{l}\text { Prohibit discrimination in all life. e.g. physical, } \\
\text { social and service environments. } \\
\text { For huge increasing in social costs, this act is } \\
\text { not universally applicable. }\end{array}$ \\
\hline 08 & \begin{tabular}{|l|} 
장애물 없는 \\
생활환경 \\
인증제도
\end{tabular} & $\begin{array}{l}\text { Set up the rule that the accessibility as well } \\
\text { as the availability by both of the disabled } \\
\text { and the old should be evaluated by the } \\
\text { nation when making the public buildings in a } \\
\text { life environment. } \\
\text { There was no obligation to follow this rule, } \\
\text { but this rule was enforced as a local } \\
\text { ordinance. }\end{array}$ \\
\hline
\end{tabular}

\subsection{Urban Railway Station and Guideline}

도시철도는 도시철도법에서 도시교통의 원활한 소통을 위 하여 도시교통권역에서 건설·운영하는 철도·모노레일·노면전 차·선형유도전동기·자기부상열차 등 궤도에 의한 교통시설 및 교통수단으로 정의하고 있다. 이중 차량 설계축중 13.5 톤 이 하의 전기철도로서 모노레일형식, 노면전차형식, 노면전차형 
식, 철제차륜형식, 고무차륜형식, 선형유도전동기형식, 자기부 상추진형식인 경량전철과 차량 설계축중 13.5 톤을 초과하는 전기철도로서 흔히 운용되고 있는 지하철인 중량전철로 구분 되고 있다.

국내 도시철도역사 관련 기준은 도시철도법과 그 하위 지 침인 도시철도 정거장 및 환승·편의시설 설계지침이 있으며, 교통약자의 이동편의 증진법이 있다. 이중 유니버설 디자인과 관련된 기준은 교통약자의 이동편의 증진법에 그 내용을 규 정하고 있으나, 항공기, 항만, 철도, 버스터미널 등 여객시설이 라는 하나의 큰 범주로만 규정하고 있어, 각 운송수단별로 고 려되어야 할 세부 항목의 규정은 미비한 실정이다.

\subsection{The Transportation Poor's Using Characteristic of Urban Railway Station}

유니버설 디자인은 다양한 사람들의 특성을 고려하여 디자 인 해결방안을 찾는 것으로 유니버설 디자인 계획기준 도출 에 있어 다양한 사용자의 행동 및 공간 이용특성을 고찰하고 이를 계획기준에 반영하는 것은 매우 중요한 일이다. 이에 교 통약자 도시철도 역사의 이용에 있어 UD관련 배려 항목 및 공간 도출을 위해 교통약자의 특성과 역사시설 이용 시나리 오를 살펴보고자 한다.

\section{1) The Transportation Poor's Characteristic}

우선, 교통약자는 장애유형에 따라 고령자, 지체부자유자 (휠체어 사용, 지팡이사용), 내부 기관장애, 시각장애, 청각장 애, 지적·정신·발달장애, 임산부, 유아동반가족, 외국인, 기타 부상 등에 의한 임시장애인 등으로 분류할 수 있다. 각 장애 유형별로 주요 대상자와 장애요소를 재분류하면 다음과 같다.

[Table 2] Categorization of Users and Major Obstacles

\begin{tabular}{|c|c|c|c|}
\hline \multicolumn{2}{|r|}{ Type } & \multirow[b]{2}{*}{\begin{tabular}{|l|}
\multicolumn{1}{|c|}{ Relevant Users } \\
\\
The wheelchair \\
users, the crutch \\
users, the old, \\
the pregnant, the \\
infants, the per- \\
son with pushing \\
a stroller, the \\
person carrying a \\
big baggage
\end{tabular}} & \multirow[b]{2}{*}{$\begin{array}{l}\text { Major Obstacles } \\
\text { - No solution of stairs and steps } \\
\text { - Difficulty of continuous walking } \\
\text { at a long distance } \\
\text { - Need more space inside of } \\
\text { automobiles and rooms } \\
\text { - Inconvenience of operating } \\
\text { facilities by only the hand for } \\
\text { the arms-handicapped } \\
\text { - No accessibility to use the } \\
\text { upper space when sitting } \\
\text { - No safety of walking by the } \\
\text { pregnant } \\
\text { - Exposed to the danger by the } \\
\text { children's unexpected behavior } \\
\text { - Need more space for changing } \\
\text { the baby's diapers }\end{array}$} \\
\hline a & $\begin{array}{l}\text { People with } \\
\text { Difficulty in } \\
\text { Walking }\end{array}$ & & \\
\hline b & $\begin{array}{l}\text { People with } \\
\text { Visual } \\
\text { Impaired }\end{array}$ & $\begin{array}{l}\text { The blind, the } \\
\text { people with a } \\
\text { low vision, the } \\
\text { children and the } \\
\text { old }\end{array}$ & $\begin{array}{l}\text { - No accessibility to visual } \\
\text { information } \\
\text { - No availability to search for the } \\
\text { routes toward the destination } \\
\text { - The difficulty to distinguish the } \\
\text { color as well as comprehending } \\
\text { the letters on the directional } \\
\text { signs }\end{array}$ \\
\hline
\end{tabular}

\begin{tabular}{|c|c|c|c|}
\hline \multicolumn{2}{|r|}{ Type } & Relevant Users & Major Obstacles \\
\hline C & $\begin{array}{l}\text { People with } \\
\text { Hearing } \\
\text { Impaired }\end{array}$ & $\begin{array}{l}\text { The deaf, the } \\
\text { person with hav- } \\
\text { ing a difficulty in } \\
\text { hearing and the } \\
\text { old }\end{array}$ & $\begin{array}{l}\text { - The difficulty of the voice } \\
\text { recognition } \\
\text { - The difficulty of recognizing the } \\
\text { aural warning } \\
\text { - Difficulty of the communication } \\
\text { with a difficulty of the } \\
\text { vocalization }\end{array}$ \\
\hline $\mathrm{d}$ & $\begin{array}{l}\text { People with } \\
\text { Difficulty in } \\
\text { Communica- } \\
\text { tion }\end{array}$ & $\begin{array}{l}\text { Foreigners, the } \\
\text { person with a } \\
\text { difficulty in vocal- } \\
\text { ization, the per- } \\
\text { son with a diffi- } \\
\text { culty in head, } \\
\text { memory or com- } \\
\text { prehending, the } \\
\text { old, the person } \\
\text { with a difficulty } \\
\text { in communica- } \\
\text { tion, the infants }\end{array}$ & $\begin{array}{l}\text { - Difficulty of information } \\
\text { recognition as well as } \\
\text { communication } \\
\text { - The difficulty of the } \\
\text { communication without } \\
\text { comprehending foreign } \\
\text { language } \\
\text { - Difficulty of reading and writing } \\
\text { - The dangerous possibility of } \\
\text { getting lost } \\
\text { - The difficulty of coping with } \\
\text { the particular situations, for } \\
\text { example search for the sanitary } \\
\text { facilities, or emergency } \\
\text { evacuation }\end{array}$ \\
\hline
\end{tabular}

质) 國土交通省、公共交通機関の旅客施設に関する移動等円滑化整備ガイ ドライン(バリアフリー整備ガイドライン 旅客施設編), 本成 25 年6, 月, p. 6 referred and rearranged by author

2) The Scenario of Access and Using Urban Railway Station

철도설계지침에 나와 있는 교통약자 편의시설 설계 지침은 교통약자가 역사를 이용함에 있어서 지상에서부터 열차를 탑 승하기까지의 전 과정에 대하여 이동 및 시설의 이용이 편리 를 도모하고 정보에의 접근을 용이하게 하기 위하여 설계단 계에서부터 교통약자가 정상인과 다름없이 생활할 수 있게끔 물리적인 환경에 대한 고려사항을 언급하고 있다.

교통약자의 역사시설 이용은 지상에서 광장, 환승주차장, 버스정류장, 보도, 자전거 등으로 접근 후 수직·수평의 이동편 의시설로 대합실로 접근할 수 있으며 대합실에서는 전화기, 화장실, 보관소, 매표소, 개·집표구, 정산소 등을 이용하는 이 용편의시설을 사용하고 다시 수직·수평 이동편의시설을 사용 한 다음 승강장으로 접근하게 된다. 승강장에서는 열차에 안 전하게 탈 수 있게 단차 및 빈틈이 없어야 한다. 이러한 공간 이용 특성을 살펴볼 때 각 공간별로 다양한 사용자를 배려하 여, 차별 없이 건축물(역사시설)을 이용할 수 있도록 하여야 하며, 각 항목별로 앞서 언급한 4 가지 장애유형을 배려하여 모두가 편리하고 안전하게 이용하도록 하여야 한다.

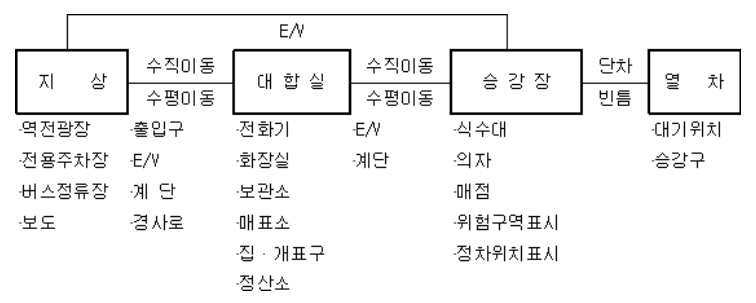

주)도시철도 정거장 및 환승.편의시설 설계지침 참고

[Figure 2] The Transportation Poor's Using Scenario of Urban Railway Station 


\section{Analysis of Universal Design Guidelines of Urban Railway Station}

\subsection{Summary}

도시철도역사의 유니버설 디자인 계획기준 도출을 위해 국 내외 관련 제도 및 기준을 고찰하고, 각 항목별 규정수준과 이 용 대상자 배려 여부를 분석하고자 한다. 비교대상인 국내외 도시철도 역사관련 유니버설디자인 제도 및 기준은 [Table 4] 와 같다. 비교분석은 교통약자 도시철도역사 이용시 배려공간 및 항목을 기준으로 각 항목별 국내외 관련 기준의 항목과 장 애요소가 있는 사용자 유형([Table 2]의 타입을 참고)을 대입 하였다.

[Table 3] Comparing and Analysis framework

\begin{tabular}{|c|c|c|c|c|c|c|c|c|c|}
\hline \multirow[b]{2}{*}{ Section } & \multicolumn{2}{|c|}{ KOR } & JPN & EU & $B R$ & \multicolumn{4}{|c|}{ Users } \\
\hline & $\begin{array}{l}\text { KR- }-~ \\
\text { act }\end{array}$ & $\begin{array}{l}\text { KR- } \\
\text { code }\end{array}$ & $\begin{array}{l}\text { JP- } \\
\text { code }\end{array}$ & $\begin{array}{l}\text { EU- } \\
\text { code }\end{array}$ & $\begin{array}{l}\text { BR- } \\
\text { code }\end{array}$ & a & $b$ & c & d \\
\hline Item or Spaces & \multicolumn{5}{|c|}{$\begin{array}{l}\text { checking with related section and } \\
\text { mandatory/recommendation }\end{array}$} & \multicolumn{4}{|c|}{$\begin{array}{l}\text { checking with } \\
\text { related user }\end{array}$} \\
\hline
\end{tabular}

1) Korea

한국은 2005년 「교통약자의 이동편의 증진법」(이하 KR-act)을 제정한 후 2006년 각 시행령과 시행규칙을 제정하 여 장애인 등의 교통수단 및 교통시설로의 접근 및 이용성을 보장해 주고 있으며, 도시철도 역사시설과 관련하여서는 「도 시철도법」에 근거하여「도시철도 정거장 및 환승-편의시설 설계지침」(이하 KR-code)을 2008년 제정 및 시행하고 있다. $\mathrm{KR}$-code의 경우 일부 장애인 및 노약자 배려 항목이 있으나, 대부분 비장애인 위주의 기준으로 KR-act와 KR-code의 적용 에 있어 일부 혼란을 줄 여지가 있다.

\section{2) Japan}

일본은 2006년 12월「고령자, 장애인 등이 원활하게 이용 할 수 있는 특정 건축물의 건축촉진에 관한 법률(하트빌딩 법)」과「교통배리어 프리법」을 일체화하여「고령자, 장애인 등의 이동 등의 원활화의 촉진에 관한 법률(배리어프리신법)」 을 제정, 시행하고 있다. 아울러, 1983년 책정 된「공공교통 터미널의 장애인 시설 정비지침」이후 지속적인 개정을 통해 $\ulcorner$ 공공교통의 이동 등 원활화정비지침(여객시설 편)」(이하 JP-code)을 최근 개정하여 시행하고 있다.12)

\section{3) Europe Union}

유럽은 범 유럽의 철도네트워크(the Trans-European Network: TEN) 구축을 위한 유럽기준을 EU의회의 승인을 얻

12) 여객터미널과 관련하여 1983년 책정 이후 1994년, 2001년, 2007년, 그리고 최근의 2013년 4번의 개정을 하였으며, 장애인 관련법의 변화와 사회적 변화에 따라 개정을 하고 있다.
어 국가별로 채택하여 사용하고 있다. 철도시설과 관련하여서 는 TSI PRM(the Technical Specifications for Interoperability: Persons with Reduced Mobility)(이하 EU-code)이 있으며, 자 국내 철도 및 역사시설이 TEN에 해당하는 경우 해당 지침 혹 은 본 규정 이상의 기준이 포함된 별도 지침을 준수하도록 하 고 있다.

\section{4) United Kingdom}

영국은 Equal Act 2010에 근거하여 건축물에 관한 접근성 보장을 위한 건축기준(Building Regulations 2010의 Part M, Approved Document $\mathrm{M}$ )과 이와 관련된 상세 기준인 $\mathrm{BS}: 8300$ 이 있다. 교통시설과 관련하여서는 철도법에 근거하 여 교통부에서 작성한 Accessible Train Station Design for Disabled People: A Code of Practice(이하 BR-code)에 의해 규제되고 있다. 이 지침은 $\mathrm{BS}: 8300$ 에 근거하여 작성하였으며, 철도역사와 관련하여 내용 및 항목을 추가하여 규제하고 있 다. BR-code는 단순히 장애인뿐만 아니라, 많은 짐을 갖고 있 는 사람이나 어린이, 유모차 이용자, 관광객과 같은 외국인 등 을 배려하여 기준별 원칙을 적용하고 있다.

[Table 4] Case Study Object of UD Law and Regulation

\begin{tabular}{l|l|l}
\hline \multicolumn{1}{c|}{ Nation } & \multicolumn{1}{|c}{ Code } & \multicolumn{1}{c}{ Name } \\
\hline \multirow{2}{*}{ Korea } & KR-act & $\begin{array}{l}\text { The Mobility Enhancement for the } \\
\text { Mobility Impaired Act }\end{array}$ \\
\cline { 2 - 3 } Japan & JP-code & $\begin{array}{l}\text { Urban Railway Station, Transfer and } \\
\text { Amenity Facilities Design Guidelines }\end{array}$ \\
\hline EU & EU-code & $\begin{array}{l}\text { 公共交通機関の 移動等円滑化整備ガイドライン } \\
\text { (旅客施設編) }\end{array}$ \\
\hline $\begin{array}{l}\text { The Technical Specifications for } \\
\text { Interoperatibility: Person with Reduced } \\
\text { Mobility }\end{array}$ \\
Kingdom & BR-code & $\begin{array}{l}\text { Accessible Train Station Design for } \\
\text { Disabled People }\end{array}$ \\
\hline
\end{tabular}

\subsection{Comparing and Analyzing: Section and Item of Law and Guidelines}

\section{1) Access Route}

접근로와 관련된 규정항목과 항목별 배려 대상자를 비교해 본 결과 국내는 사전 여행계획 수립정보제공(웹 등을 통해 이 용가능 연계교통수단, 화장실 및 수직이동 시설 등에 대한 정 보제공), 전체 이동 가능한 동선계획 수립 및 정보제공, 공사. 보수기간 중 접근성 보장(우회동선 안내 및 보행안전통로 임 시 확보방안), 주차관련 단속과 이용가능 주차공간의 정보제 공, 조명, 드랍오프존 등에서의 기준이 미비한 것으로 나타났 다. 특히, 역사시설의 접근과 관련하여 승강장까지 이르는 전체 보행동선에 대해 연속적이고 안전한 보행동선 계획 수립 및 이 
에 대한 사전 정보제공은 대부분의 사용자에게 혜택이 돌아가 는 중요한 항목으로 이에 대한 보완이 필요해 보인다.(Table 5)

[Table 5] Comparing of Access Route Section

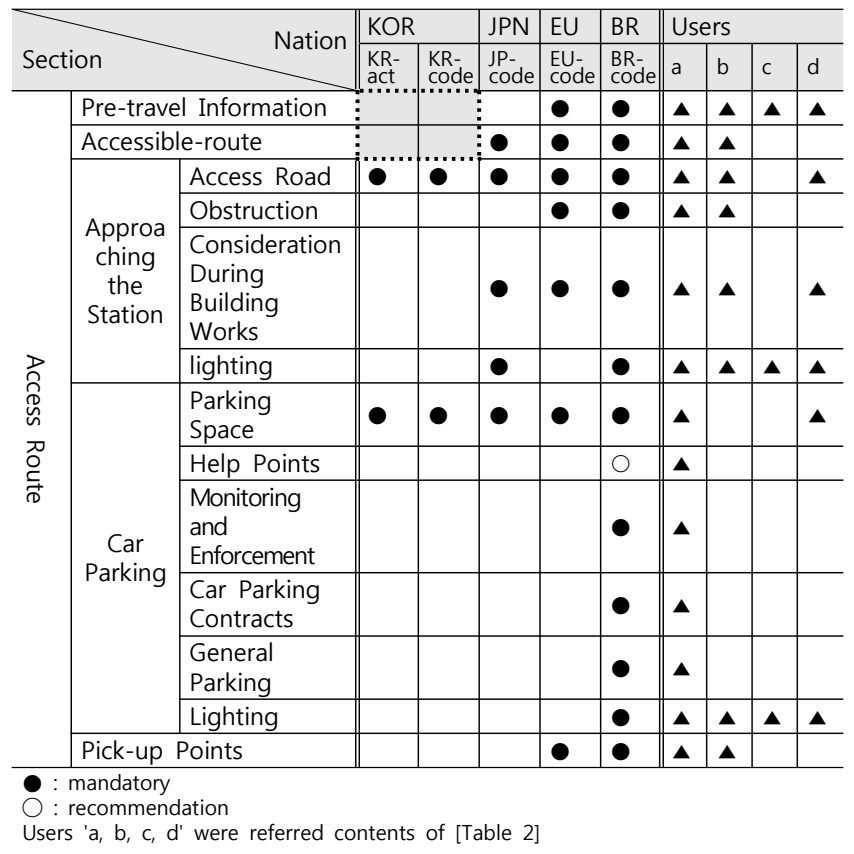

\section{2) Route and Vertical Moving}

역사내 통로 및 수직이동과 관련된 규정항목과 항목별 배 려 대상자를 비교해본 결과 국내는 통로와 관련하여 역사내 가구와 같은 기타시설과 조도확보의 규정기준이 미비한 것으 로 나타났다. EU와 영국의 경우 역사내 설치되는 가구 등과 주변 바닥, 벽체 색상의 시인성 및 보행장애요소 제거 사항 등 을 구체적으로 명시하고 있다. 수직이동 시설과 관련하여 $\mathrm{KR}$-code의 경우 현재 사용을 지양하고 있는 휠체어 리프트의 기준을 명시하고 있고, 그 외 경사로, 에스컬레이터의 장애인 등을 배려한 기준이 미비하여 현장 실무자가 참고하는데 있 어 혼란을 줄 소지가 있다. 또한 국외와 비교하여 무빙워크, 에스컬레이터의 세부기준이 다양한 장애유형(유럽과 영국에 서는 시각 장애인의 경우 에스컬레이터, 무빙워크의 이용을 지양하고, 승강기나 계단을 이용하도록 규정하고 있음)에 따 라 구체적인 대응방안이 필요해 보인다.(Table 6)

\section{3) Toilet}

역사내 위생시설과 관련된 규정항목과 항목별 배려 대상자를 비교해본 결과 국내는 다목적 화장실의 설치, 화장실에 대한 상 세기능안내, 응급상황시의 비상호출시설, 일반화장실의 대변기, 기저귀 교환시설의 기준이 미비한 것으로 나타났다. 도시철도역 사와 같은 시설은 다양한 사용계층과 다른 공공시설대비 많은 인원이 이용하는 시설로 유니버설 디자인 관점에서 위생시설과
관련된 보조적인 시설에 대한 기준이 강화될 필요가 있다. 특히, 응급상황시 이용할 수 있는 비상호출시설은 안전 및 생명과 직 결된 사항으로 필수적으로 규정되어야 할 항목이다.(Table 7)

[Table 6] Comparing of Route and Vertical Moving Section

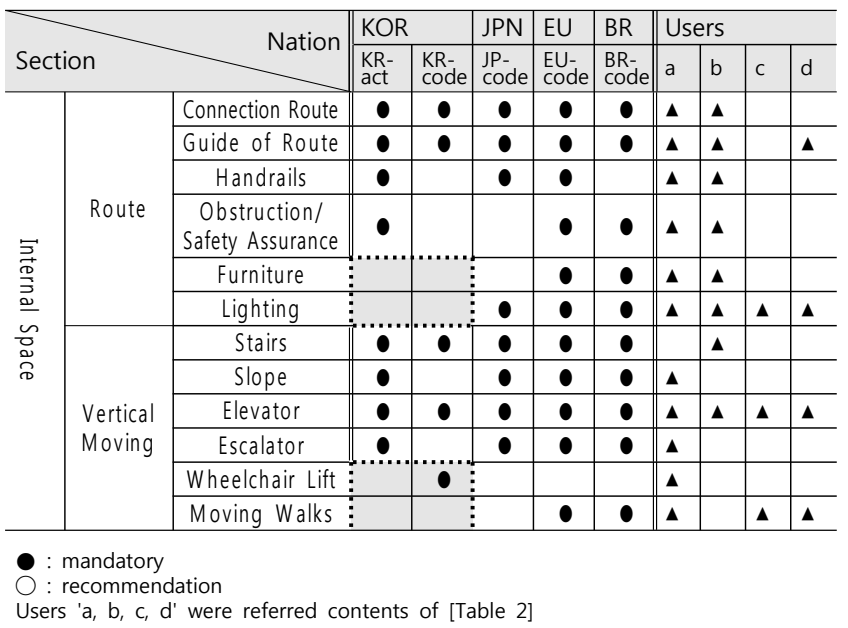

[Table 7] Comparing of Toilet Section

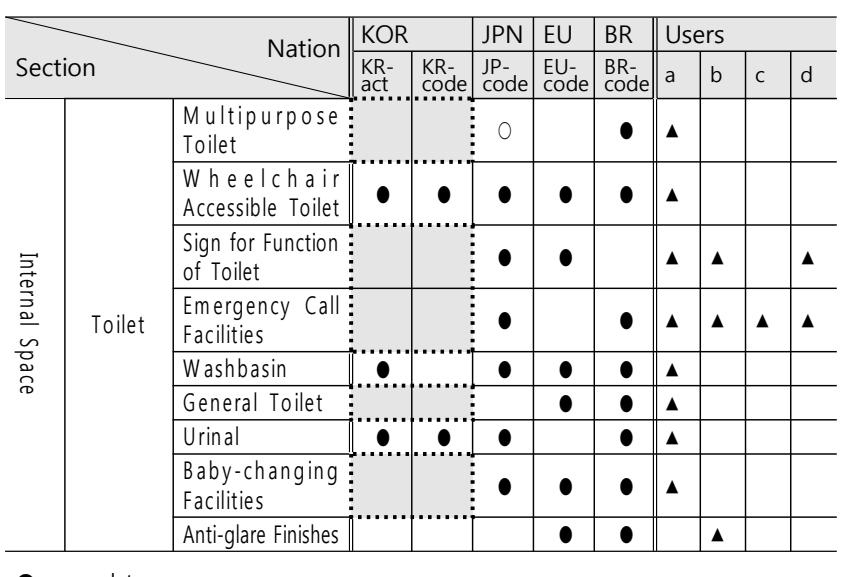

: mandatory

sers 'a, b, c, d' were referred contents of [Table 2]

\section{4) Ticket Gate lines and Platforms}

매표소, 개찰구, 승강장과 관련된 규정항목과 항목별 배려 대상자를 비교해본 결과 국내는 매표소에서의 통화장치(유리 칸막이로 인한 의사소통 어려움, 언어 장애인을 배려한 수화 통화 장치 등)와 승강장에서의 조명 등에 대한 기준이 미비한 것으로 나타났다. 긴급대피시설의 경우 국내뿐만 아니라 일 본, $\mathrm{EU}$, 영국의 기준에서도 규정하고 있지 않고 있는 실정이 다. 지하철내 화재 및 재난시의 대피구조, 피난 설비에 대한 것은 신체적, 정신적으로 능력이 떨어지는 교통약자에게 더 중요한 사항으로 이에 대한 규정 및 기준 보완이 시급해 보인 다.(Table 8) 
[Table 8] Comparing of Ticket Gate lines and Platforms Section

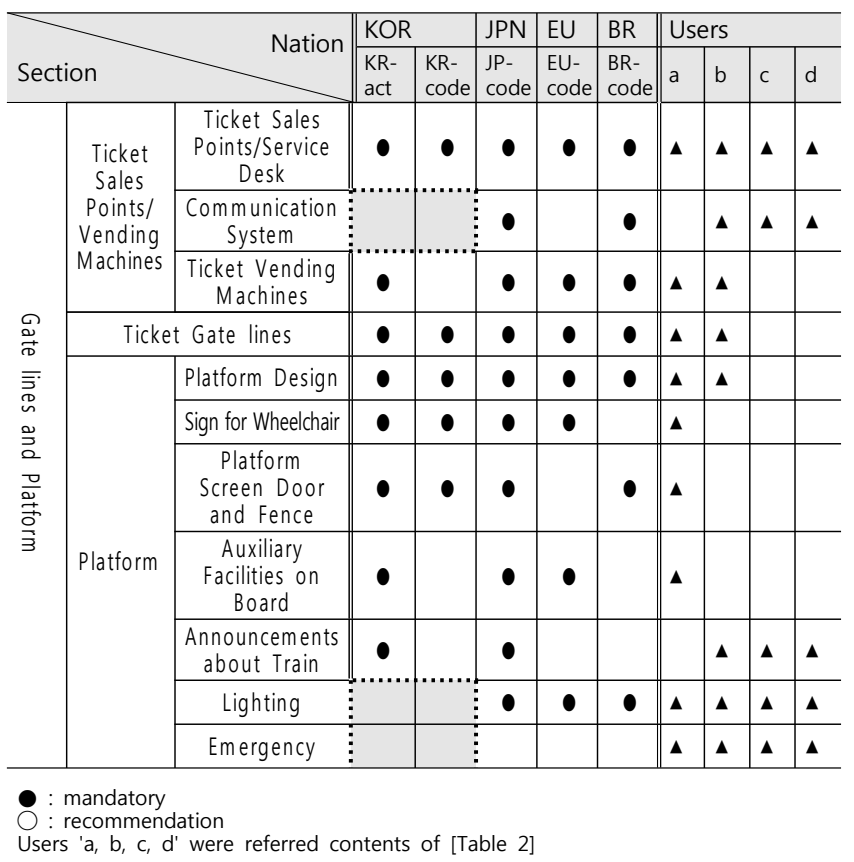

\section{5) Guidance and Signs}

역사내 유도 및 안내시설과 관련된 규정항목과 항목별 배려 대상자를 비교해본 결과 국내는 역사주변안내(역 주변 장애인 등이 이용 가능한 환승교통정보, 이용 가능 보행루트 등)와 종합 안내 연속적인 방향안내, 안내판내 조명, 음성안내, LED Display Screens, 도움호출벨 등에 대한 기준이 미비한 것으로 나타났다. 역사내부 유도, 안내시설의 경우 단순히 시각장애인 만을 위한 사항이 아닌 복잡한 역사시설을 이용하는 다양한 사용자를 배려 해야 하는 사항으로 국외의 경우 안내시설의 배경과 안내판의 내부 색상, 글자, 크기에 대한 상세 기준을 제시하고 있으며, 일 정한 조도 확보를 위한 조명기준도 명시하고 있다.

현재 도시철도역사 내부 시설의 종합안내도 및 방향안내, 스크린 및 음성안내가 제공되고 있으나, 장애인, 외국인, 어 린이 등을 배려한 상세기준은 마련되어 있지 않은 실정이 다. 영국과 유럽 기준의 경우 난청자 등을 배려하여 음성안 내의 볼륨과 안내 속도에 대한 사항까지 규정하고 있으며, 스크린 안내에 있어서도 글자의 색상 및 화면에 머무르는 지속시간, 키가 작은 사람 및 휠체어 사용자 등을 배려한 설 치 높이, 화면의 각도 등에 대한 사항까지 명시하고 있다. 아울러, 스마트폰이나 PDA등을 통한 휴대용 내비게이션 시 스템까지 구비할 것을 권장하고 있는 상황으로 국내에서도 유도 및 안내시설 기준에 대한 보완이 시급해 보인다. 또한 응급상황시 이용할 수 있는 비상호출시설은 안전 및 생명과 직결된 사항으로 필수적으로 규정되어야 할 항목이 다.(Table 9)
[Table 9] Comparing of Guidance and Signs Section

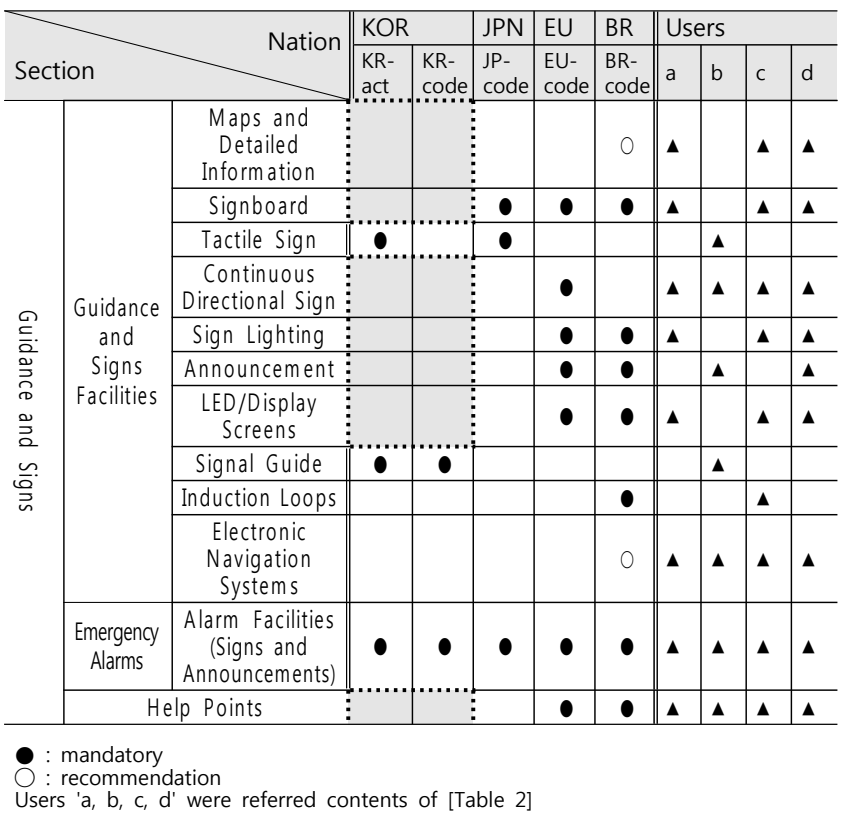

6) The Others

역사내 기타사항과 관련된 규정항목과 항목별 배려 대상자 를 비교해본 결과 국내는 통신시설 및 휴게시설과 직원에 대 한 교육에 대한 기준이 미비한 것으로 나타났다. 일본의 경우 외국인 관광객 및 장애인 등의 공중전화 사용을 고려해 상세 기준을 명시하고 있으며, 유럽의 경우 역사의 시설관리자, 열 차운행자 등을 대상으로 장애 및 평등에 관한 교육 이수를 의 무적으로 명시하여, 보다 나은 서비스체계를 구축하고 있 다.(Table 10)

[Table 10] Comparing of the Others Section

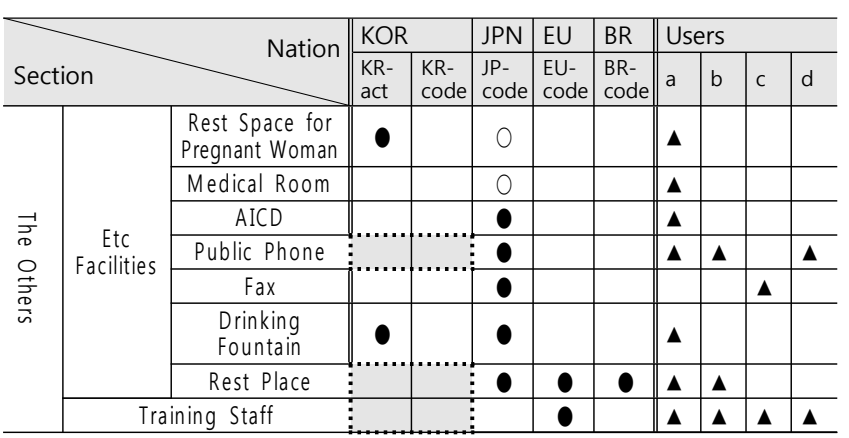

mandatory

sers 'a, b, $c$, $d$ ' were referred contents of [Table 2]

\section{Findings of Universal Design Critical Factors for Urban Railway Station}

앞서 분석한 항목별 규정빈도와 규정강도 및 배려 대상자 빈도를 비교하여 도시철도역사의 유니버설 디자인 기준요소 를 도출하면 [Table 11]과 같다. 
[Table 11] UD Critical Factors of Urban Railway Station

\begin{tabular}{|c|c|c|c|}
\hline \multicolumn{3}{|l|}{ Section } & \multirow{2}{*}{ Crieria } \\
\hline \multirow{11}{*}{$\begin{array}{l}\text { Access } \\
\text { Route }\end{array}$} & \multicolumn{2}{|c|}{ Pre-travel Information } & \\
\hline & \multicolumn{2}{|c|}{ Accessible-route } & $\bullet$ \\
\hline & \multirow{4}{*}{$\begin{array}{l}\text { Approaching } \\
\text { the Station }\end{array}$} & Access Road & - \\
\hline & & Obstruction & $\bullet$ \\
\hline & & $\begin{array}{l}\text { Consideration during Building } \\
\text { Works }\end{array}$ & • \\
\hline & & lighting & 0 \\
\hline & \multirow{4}{*}{ Car parking } & Parking Space & $\bullet$ \\
\hline & & Help Points & 0 \\
\hline & & Monitoring and Enforcement & 0 \\
\hline & & Lighting & 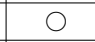 \\
\hline & \multicolumn{2}{|l|}{ Pick-up Points } & $\bullet$ \\
\hline \multirow{20}{*}{$\begin{array}{l}\text { Internal } \\
\text { Space }\end{array}$} & \multirow{6}{*}{ Route } & Connection Route & $\bullet$ \\
\hline & & Guide of Route & $\bullet$ \\
\hline & & Handrails & $\bullet$ \\
\hline & & Obstruction/Safety Assurance & $\bullet$ \\
\hline & & Furniture & $\bullet$ \\
\hline & & Lighting & $\bullet$ \\
\hline & \multirow{5}{*}{ Vertical Moving } & Stairs & $\bullet$ \\
\hline & & Slope & - \\
\hline & & Elevator & $\bullet$ \\
\hline & & Escalator & $\bullet$ \\
\hline & & Moving Walks & 0 \\
\hline & \multirow{9}{*}{ Toilet } & Multipurpose Toilet & 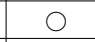 \\
\hline & & Wheelchair Accessible Toilet & $\bullet$ \\
\hline & & Sign for Function of Toilet & $\bullet$ \\
\hline & & Emergency Call Facilities & $\bullet$ \\
\hline & & Washbasin & $\bullet$ \\
\hline & & General Toilet & 0 \\
\hline & & Urinal & $\bullet$ \\
\hline & & Baby-changing Facilities & $\bullet$ \\
\hline & & Anti-glare Finishes & $\bullet$ \\
\hline \multirow{11}{*}{$\begin{array}{c}\text { Gate } \\
\text { lines } \\
\text { and } \\
\text { Platfor } \\
\mathrm{m}\end{array}$} & \multirow{3}{*}{$\begin{array}{l}\text { Ticket Sales } \\
\text { Points/Vending } \\
\text { Machines }\end{array}$} & Ticket Sales Points/Service Desk & $\bullet$ \\
\hline & & Communication System & $\bullet$ \\
\hline & & Ticket Vending Machines & $\bullet$ \\
\hline & \multicolumn{2}{|c|}{ Ticket Gate lines } & $\bullet$ \\
\hline & \multirow{7}{*}{ Platform } & Platform Design & $\bullet$ \\
\hline & & Sign for Wheelchair & - \\
\hline & & Platform Screen Door and Fence & $\bullet$ \\
\hline & & Auxiliary Facilities on Board & $\bullet$ \\
\hline & & Announcements about Trains & $\bullet$ \\
\hline & & Lighting & $\bullet$ \\
\hline & & Emergency Facilities & $\bullet$ \\
\hline \multirow{10}{*}{$\begin{array}{l}\text { Guidance } \\
\text { and } \\
\text { Signs }\end{array}$} & \multirow{8}{*}{$\begin{array}{l}\text { Guidance and } \\
\text { Signs Facilities }\end{array}$} & Maps and Detailed Information & O \\
\hline & & Signboard & - \\
\hline & & Tactile Sign & $\bullet$ \\
\hline & & Continuous Directional Sign & $\bullet$ \\
\hline & & Sign Lighting & $\bullet$ \\
\hline & & Announcement & $\bullet$ \\
\hline & & LED/Display Screens & $\bullet$ \\
\hline & & Signal Guide & $\bullet$ \\
\hline & $\begin{array}{l}\text { Alarming and } \\
\text { Emergency }\end{array}$ & $\begin{array}{l}\text { Alarm Facilities(Signs and } \\
\text { Announcements) }\end{array}$ & $\bullet$ \\
\hline & Help Points & & - \\
\hline & & Rest Space for Pregnant Woman & O \\
\hline & & Public Phone & $\bullet$ \\
\hline $\begin{array}{l}\text { The } \\
\text { Others }\end{array}$ & Etc racilities & Drinking Fountain & O \\
\hline & & Rest Place & $\bullet$ \\
\hline & Training Staff & & $\bullet$ \\
\hline
\end{tabular}

접근로와 관련하여 사전이동정보제공과 각 시설별 접근 가 능한 동선계획 수립의무 및 이에 대한 정비를 하도록 하며, 공 사 및 보수공사 기간 중 우회 동선 확보와 이에 대한 동선안 내정보를 제공하도록 한다. 주차공간과 관련하여 주차구역 및 이에 대한 안내를 의무화하고, 부가적인 안내시설, 도움 호출 벨, 주차가능공간에 대한 정보제공 및 관련시설 정비는 권장 사항으로 둔다. 역사내 연결통로 및 대합실과 관련하여 시각 장애인 및 기타 정보장애인 등을 배려하여 유도시설 기준을 의무화하고, 보행장애물제거 및 가구시설에 대한 설치 기준을 의무화한다. 수직이동시설과 관련하여 기존 지침에 명시되어 있던 휠체어 리프트사항을 설치금지하며, 무빙워크의 경우 시 각장애인, 휠체어 사용자 등의 이용을 고려한 기준을 권장토 록 한다. 위생시설과 관련하여 다양한 사용자에 대응하는 다 목적화장실 설치 기준을 권장화하고, 화장실내 안내 및 위급 상황시 이용할 수 있는 시설에 대한 기준을 의무화한다. 아울 러, 기저귀 교환대와 같은 항목을 의무화하고 일반화장실내 대변기에 대한 기준을 권장화 한다. 개찰구, 승강장과 관련하 여 매표소의 의사소통 장치기준을 의무화하고, 승강장내 조명 및 피난시설에 대한 기준을 의무화한다. 유도 및 안내시설과 관련하여 시각, 음성, 디스플레이 안내 및 도움 호출벨 등에 대한 상세 설치 기준을 마련하고 설치를 의무화한다. 기타 임 산부휴게시설 및 음수대 설치를 권장화 하고 직원 및 시설 운 영자 교육을 의무화하여 물리적 환경뿐만 아니라 인적서비스 차원에서의 유니버설디자인을 도모하도록 한다.

\section{Conclusion}

본 연구는 국내외 도시철도역사의 유니버설디자인 관련 기 준의 비교·분석을 통해 도시철도역사의 유니버설 디자인 기준 요소를 도출한 연구로, 주요 연구결과 및 제언을 정리하면 다 음과 같다.

첫째, 본 연구는 도시철도역사 이용자의 이용행태 및 공간 이용시나리오를 기반으로 접근로, 주차공간, 통로 및 대합실, 수직이동시설, 위생시설, 개찰구 및 승강장, 유도 및 안내시설, 기타 편의시설의 항목으로 구분하고, 각 항목별로 한국, 일본, 유럽, 영국의 관련 기준의 규정빈도 및 강도와 배려 대상자 빈 도 비교를 통해 도시철도 역사의 유니버설 디자인 기준요소 를 도출하였다.

둘째, 연구를 통해「교통약자의 이동편의 증진법」은 교통 관련 여객시설의 큰 범주로 규제하고 있어, 시설별 세부 설계 지침이 부재함을 알 수 있었으며,「도시철도법」에 근거한「도 시철도 정거장 및 환승·편의시설 설계지침」은 그 이용 대상자 를 비장애인으로 한정하며, 그나마 일부 항목에 명시하고 있 는 장애인 관련 기준도 교통약자의 이동편의 증진법과 상충 되는 부분이 있어, 각 기준을 통합하여 규제할 수 있는 유니버 
설디자인 철학에 적합한 제도적 기준마련이 필요함을 알 수 있었다.

셋째, 국내외 관련 기준 및 항목별 철도시설 이용자 배려사 항을 비교분석한 결과 국외에서는 다양한 사용자 계층에 대 한 배려와 더불어 특별한 상황에 대한 개별적 대응 기준도 명 시하고 있었다. 예를 들어 사용빈도가 적은 청각감응장치와 같은 사항에 대해서도 설치를 의무화하였다. 이는 유니버설 디자인이 단순히 하나의 해결책으로 모두에게 혜택이 돌아가 는 것이 아닌, 범용적 해결책과 더불어 개별적 대응이 가능한 해결책이 필요함을 시사한다.

넷째, 유니버설 디자인 계획기준은 국외 기준에 명시된 것 처럼 단순히 물리적 환경에 한정된 것이 아니라 시설 운영 및 관리자의 인식적 차원의 유니버설디자인화까지 확대될 필요 가 있다. 물리적 환경 개선과 더불어 시설 운영 및 관리자의 인식변화는 질적으로 향상된 서비스를 제공해주게 될 것이며, 이는 궁극적으로 좀 더 나은 환경을 제공하게 될 것이기 때문 이다.

마지막으로 본 연구는 철도시설의 국내외 유니버설 디자인 관련 기준 비교 분석을 통해 도시철도역사의 유니버설 디자 인 기준요소를 도출한 연구로 향후에 도출된 기준요소를 바 탕으로 각 항목별 세부기준 개발을 위한 후속연구가 필요할 것이다.

Acknowledgements: This research was supported by a grant (13RTRP-B067918-01) from Railroad Technology Research Program funded by Ministry of Land, Infrastructure and Transport of Korean government

\section{References}

British Standards Institution, 2010, BS:2009, United Kingdom Department for Transport, 2011, Accessible Train Station Design for Disabled People: A Code of Practice, United Kingdom

European Union, 2008, Technical Specification of Interoperability: Persons with reduced Mobility, European Union

Mace, Ronald L., Hardie, Graeme J. \& Place, Jaine P., 1991, Accessible Environments: Toward Universal Design in W.E. Preiser, J.C. Vischer, E.T. White(Eds.). Design intervention: Toward a more humane architecture, Van Nostrand Reinhold, NY

Ministry of Land, Infrastructure and Transport, 2013, Urban Railway Station, Transfer and Amenity Facilities Design Guidelines, South Korea

Ministry of Land, Infrastructure and Transport, 2013, "the Mobility Enhancement for the Mobility Impaired Act", South Korea

Story, F.S., J.L.Mueller and R.L.Mace., 1998, The Universal Design File: Designing for People of all ages and abilities, North Carolina State University(The Center for Universal Design), NC

國土交通省，2006，“高齢者、障害者等の移動等の円滑化の促進に関す る法律 ( バリアフリー法)", 日本

國土交通省，2013，公共交通機関の旅客施設に関する移動等円滑化整備
ガイドライン(バリアフリー整備ガイドライン 旅客施設編)，日本

접수 : 2014년 03월 31일 1차 심사 완료 : 2014년 04월 18일 게재확정일자 : 2014년 05월 08일 3인 익명 심사 필 